\title{
The KIGS Experience with the Addition of Gonadotropin-Releasing Hormone Agonists to Growth Hormone (GH) Treatment of Children with Idiopathic GH Deficiency
}

\author{
Edward O. Reiter ${ }^{a}$ Anders Lindberg ${ }^{b}$ Michael B. Ranke ${ }^{c}$ David A. Price $^{d}$ \\ Kerstin Albertsson-Wikland ${ }^{\mathrm{e}}$ Christopher T. Cowell ${ }^{f}$ Bert Bakker ${ }^{b}$ \\ on behalf of the KIGS International Board \\ aBaystate Medical Center Children's Hospital, Tufts University School of Medicine Springfield, Mass., USA; \\ bPharmacia Corporation, KIGS/KIMS Outcomes Research, Stockholm, Sweden; 'Paediatric Endocrinology Section, \\ University Children's Hospital, Tübingen, Germany; ${ }^{d}$ Royal Manchester Children's Hospital, Manchester, UK; \\ ePediatric Growth Research Centre, University of Göteborg, Göteborg, Sweden; ${ }^{f}$ Institute of Endocrinology, \\ Parramatta, Australia
}

\section{Key Words}

Growth hormone $\cdot$ KIGS $\cdot$ Children $\cdot$ Pubertal maturation. Gonadotropin-releasing hormone agonists - Idiopathic growth hormone deficiency . Near-final height

\begin{abstract}
Although recombinant techniques have enabled the production of limitless amounts of human growth hormone $(\mathrm{GH})$, and clinical methods for diagnosis and treatment have been greatly enhanced, the mean final heights of children with idiopathic GH deficiency (IGHD) treated with $\mathrm{GH}$ remain in the range of -1.3 standard deviation scores (SDS) below normal height. One of the methods used to increase height outcomes is to delay the onset and progression of puberty to allow for a longer 'prepubertal' growth phase. We reviewed the KIGS (Pharmacia International Growth Database) data of patients with IGHD who had been treated with gonadotropin-releas-
\end{abstract}

\section{KARGER}

Fax + 41613061234

E-Mail karger@karger.ch

www. karger.com
(C) 2003 S. Karger AG, Basel

0301-0163/03/0607-0068\$19.50/0

Accessible online at:

www. karger.com/hre ing hormone agonists ( $\mathrm{GnRHa}$ ) in order to see if a greater gain in height could be achieved by altering the tempo of pubertal maturation. Near-final height data were analysed in 39 adolescents (out of a total of 249) who had received $\mathrm{GH}+\mathrm{GnRHa}$ therapy and were compared with similar data from 1,893 patients with IGHD treated with $\mathrm{GH}$ alone. The total change in height SDS in boys who received $\mathrm{GH}$ alone was +1.6, in contrast to +1.1 in $\mathrm{GH}+$ GnRHa-treated boys; the total change in height SDS in girls who received $\mathrm{GH}$ alone was +1.4 in contrast to +1.1 in girls treated with $\mathrm{GH}+\mathrm{GnRHa}$. The near final height SDS in girls treated with $\mathrm{GH}+\mathrm{GnRHa}$ was 1.0 below the mid-parental target height (MPH), whereas there was only a -0.5 SDS difference in girls treated with $\mathrm{GH}$. Approximation to the MPH did not differ in boys between the two treatment groups. These data suggest that the attainment of a substantial height SDS by manipulating the tempo of puberty is limited, but that optimizing growth during the pre-pubertal phase is a more important factor.

Prof. E.O. Reiter

Baystate Medical Center Children's Hospital

Tufts University School of Medicine

Springfield, MA 01199 (USA)

Tel. +1 413794 5060, Fax +1 413794 3623, E-Mail edward.reiter@bhs.org 


\section{Introduction}

Patients with growth hormone deficiency (GHD) who receive treatment with biosynthetic growth hormone $(\mathrm{GH})$ have markedly improved actual or near-final height (NFH) outcomes, with an average final height approximating -1.3 standard deviations (SD) below the mean reported in more than 1,400 patients from different registries and trials [1-11]. Yet despite the availability of modern GH therapy, long-term studies still show that the majority of patients fail to achieve their genetic target heights. Evaluation of final heights in 121 patients treated in $\mathrm{GH}$ research trials conducted by Genentech indicated a mean height standard deviation score (SDS) of -0.7 , with 106 patients being within 2.0 SDS of normal adult height in the USA [4]. Nevertheless, even in these patients, a -0.4 to -0.6 SDS difference from mid-parental target height (MPH) still occurred. Achievement of the genetic target height is possible, as shown with a Swedish subgroup (from KIGS [Pharmacia International Growth Database]) of consistently treated patients who reached a median final height SDS of -0.32 , which was equivalent to the MPH [11]. The data from this Swedish subgroup, however, are atypical.

As final height correlates with height at the onset of puberty in patients with GHD [2, 12-15], every effort must be made to optimize growth velocity during prepuberty and to achieve a height within the normal range at the onset of puberty. In data from two large international data registries (National Cooperative Growth Study [NCGS] and KIGS), the height gained during puberty in patients with GHD was generally similar to that of healthy children with delayed bone age $[9,16]$. Pubertal height gain is negatively correlated with age at the onset of puberty; it is known, for example, that patients with GHD with delayed puberty or hypogonadotropic hypogonadism achieve a taller height in adulthood $[13,17,18]$.

Precocious puberty can reduce the response to $\mathrm{GH}$, and so it may be an appropriate step to delay puberty with a GnRH agonist (GnRHa) [19-21]. It is not yet clearly documented, however, whether the use of this strategy in pubertal patients with GHD can enhance the final height [22-28]. Small, controlled studies in adolescents with GHD [26, 29] have shown that achievement of the MPH is possible when a GnRHa is added to the treatment regimen. When these results were compared with data from the large NCGS database, however, the NCGS data did not show greater gains with the use of GnRHa in a number of height growth parameters, other than a small gain in predicted final height before GH therapy in comparison with treatment with $\mathrm{GH}$ alone [30]. It seemed appropriate, therefore, to review the KIGS data on patients with idiopathic GHD (IGHD) treated with GnRHa in order to report the efficiency of a large multinational registry.

\section{Methods}

In total, 42,206 patients from 47 countries were entered in the KIGS database as of August 2002, with 21,392 children of those having IGHD receiving therapy with GH alone (table 1). Out of these 42,206 children, 249 were treated with a variety of regimens that included GnRHa. The diagnosis of IGHD was made by the individual KIGS investigator according to the KIGS Aetiology Classification List and was based on a maximal level of $\mathrm{GH}$ of less than $10 \mathrm{ng} / \mathrm{ml}$ in two standard GH stimulation tests. Neuroimaging had been performed in $45 \%$ of the patients and patients with structural abnormalities in the hypothalamic-pituitary area were excluded.
Table 1. Baseline characteristics of all boys and girls with IGHD in KIGS: treatment with $\mathrm{GH}$ alone vs. $\mathrm{GH}+\mathrm{GnRHa}$

\begin{tabular}{|c|c|c|c|c|}
\hline & \multicolumn{2}{|l|}{ Boys } & \multicolumn{2}{|l|}{ Girls } \\
\hline & GH alone & $\mathrm{GH}+\mathrm{GnRHa}$ & GH alone & $\mathrm{GH}+\mathrm{GnRHa}$ \\
\hline Patients, $n$ & 14,612 & 109 & 6,780 & 140 \\
\hline $\begin{array}{l}\text { Age at start of GH treatment, } \\
\text { years }\end{array}$ & 10.3 & 11.3 & 10.1 & 10.6 \\
\hline Bone age, years & 8.0 & 10.0 & 8.0 & 8.5 \\
\hline Ht SDS & -2.4 & -2.3 & -2.6 & -2.4 \\
\hline MPH SDS & -1.0 & -1.0 & -1.0 & -1.0 \\
\hline $\mathrm{Ht}-\mathrm{MPH}$ & -1.5 & -1.4 & -1.6 & -1.4 \\
\hline Dose of $\mathrm{GH}, \mathrm{mg} / \mathrm{kg} /$ week & 0.2 & 0.2 & 0.2 & 0.2 \\
\hline
\end{tabular}

All values, except for the number of patients, are expressed as medians. $\mathrm{Ht}=$ Height; $\mathrm{MPH}=$ mid-parental target height .
GH and GnRHa Treatment of Children in KIGS 
Table 2. Baseline characteristics of boys and girls with IGHD who had achieved near-final height: treatment with $\mathrm{GH}$ alone vs. $\mathrm{GH}+\mathrm{GnRHa}$

\begin{tabular}{|c|c|c|c|c|}
\hline & \multicolumn{2}{|l|}{ Boys } & \multicolumn{2}{|l|}{ Girls } \\
\hline & GH alone & $\mathrm{GH}+\mathrm{GnRHa}$ & GH alone & $\mathrm{GH}+\mathrm{GnRHa}$ \\
\hline Patients, $\mathrm{n}$ & 1,170 & 16 & 723 & 23 \\
\hline $\begin{array}{l}\text { Age at start of GH treatment, } \\
\text { years }\end{array}$ & 10.0 & 11.0 & 9.0 & 9.6 \\
\hline Bone age, years & 7.5 & 8.6 & 6.8 & 8.0 \\
\hline Ht SDS & -2.6 & -2.3 & -2.8 & -2.5 \\
\hline MPH SDS & -0.8 & -1.1 & -0.8 & -0.7 \\
\hline $\mathrm{Ht}-\mathrm{MPH}$ & -2.0 & -1.0 & -2.1 & -1.7 \\
\hline Dose of $\mathrm{GH}, \mathrm{mg} / \mathrm{kg} /$ week & 0.2 & 0.2 & 0.2 & 0.2 \\
\hline
\end{tabular}

All values, except for the number of patients, are expressed as medians. Ht = Height; $\mathrm{MPH}=$ mid-parental target height .
Table 3. Characteristics of boys and girls with IGHD who had achieved near-final height: at the start of puberty and the start of GnRHa therapy

\begin{tabular}{llllll}
\hline & \multicolumn{2}{l}{ Boys } & & & \multicolumn{2}{l}{ Girls } \\
\cline { 2 - 3 } \cline { 5 - 6 } & GH alone & GH + GnRHa & & GH alone & GH + GnRHa \\
\hline Stage & Tanner 2 & Start GnRHa & & Tanner 2 & Start GnRHa \\
Patients, $n$ & 480 & 16 & & 294 & 23 \\
Age at start of GH treatment & 13.4 & 13.0 & & 12.2 & 11.5 \\
Bone age & 12.3 & 12.0 & & 10.8 & 10.2 \\
Ht SDS & -1.6 & -1.8 & & -1.8 & -1.8 \\
$\Delta$ Ht SDS & +1.0 & +0.7 & & +1.0 & +0.7 \\
Ht - MPH & -1.0 & -0.3 & & -1.0 & -1.1 \\
\hline
\end{tabular}

All values, except for the number of patients, are expressed as medians. $\mathrm{Ht}=$ Height; $\mathrm{MPH}=$ mid-parental target height.
Near-final height (NFH) was defined by a height velocity of less than $2 \mathrm{~cm} /$ year as calculated over a period of more than 9 months, a chronological age of more than 16 years in boys and more than 14 years in girls, or bone ages no less than 14 years in boys and 13 years in girls. GH therapy was at least 4 years in duration, with 1 year of pre-pubertal treatment. MPH was calculated and expressed as an SDS, as described by Ranke et al. [16]. NFH was expressed in three different ways, which are complementary to each other: (1) the actual height expressed as a height SDS; (2) the increment of height gained (or change in height SDS), represented as NFH minus initial height SDS; (3) the approximation to family target height, represented by NFH minus MPH SDS.

Data from 1,893 patients with IGHD treated with GH alone and 39 patients with IGHD treated with $\mathrm{GH}+\mathrm{GnRHa}$, all of whom had reached NFH, are described in this report (table 2). The details of the regimens used by the investigators to suppress the hypothalamicpituitary-gonadal axis and delay the onset and/or progression of puberty are not described in this report, as this information is not readily available from the database.

\section{Results}

Baseline characteristics of 1,893 GH-treated and 39 $\mathrm{GH}+$ GnRHa-treated patients with IGHD, who had reached NFH are shown in table 2 . In contrast to the $62 \%$ prevalence of boys in the GH-treated group, only $41 \%$ of children treated with GH + GnRHa were boys. The children who required GnRHa therapy were older, with significantly more advanced skeletal maturation $(\mathrm{p}<0.01)$. The groups were comparable in short stature and in height deficits relative to family targets.

The characteristics describing the patients at the onset of puberty in the GH-treated group and at the start of GnRH therapy are shown in table 3. Approximately $90 \%$ of the children in whom agonist treatment was initiated were in early puberty. There were no auxological differences between the two patient groups except a change in height SDS in which the GH + GnRHa groups had a significantly lower incremental gain $(\mathrm{p}<0.01)$.

\footnotetext{
$\overline{70} \quad$ Horm Res 2003;60(suppl 1):68-73
} 
Fig. 1. Height SDS (Ht SDS) at the start of GH therapy, at near-adult height (NAH)/ near-final height (NFH) and at NFH corrected for mid-parental height (MPH) in (a) boys and (b) girls with IGHD: treatment with $\mathrm{GH}$ alone versus $\mathrm{GH}+\mathrm{GnRHa}$.

Table 4. Characteristics of boys and girls with IGHD at near-final height

GH and GnRHa Treatment of Children in KIGS

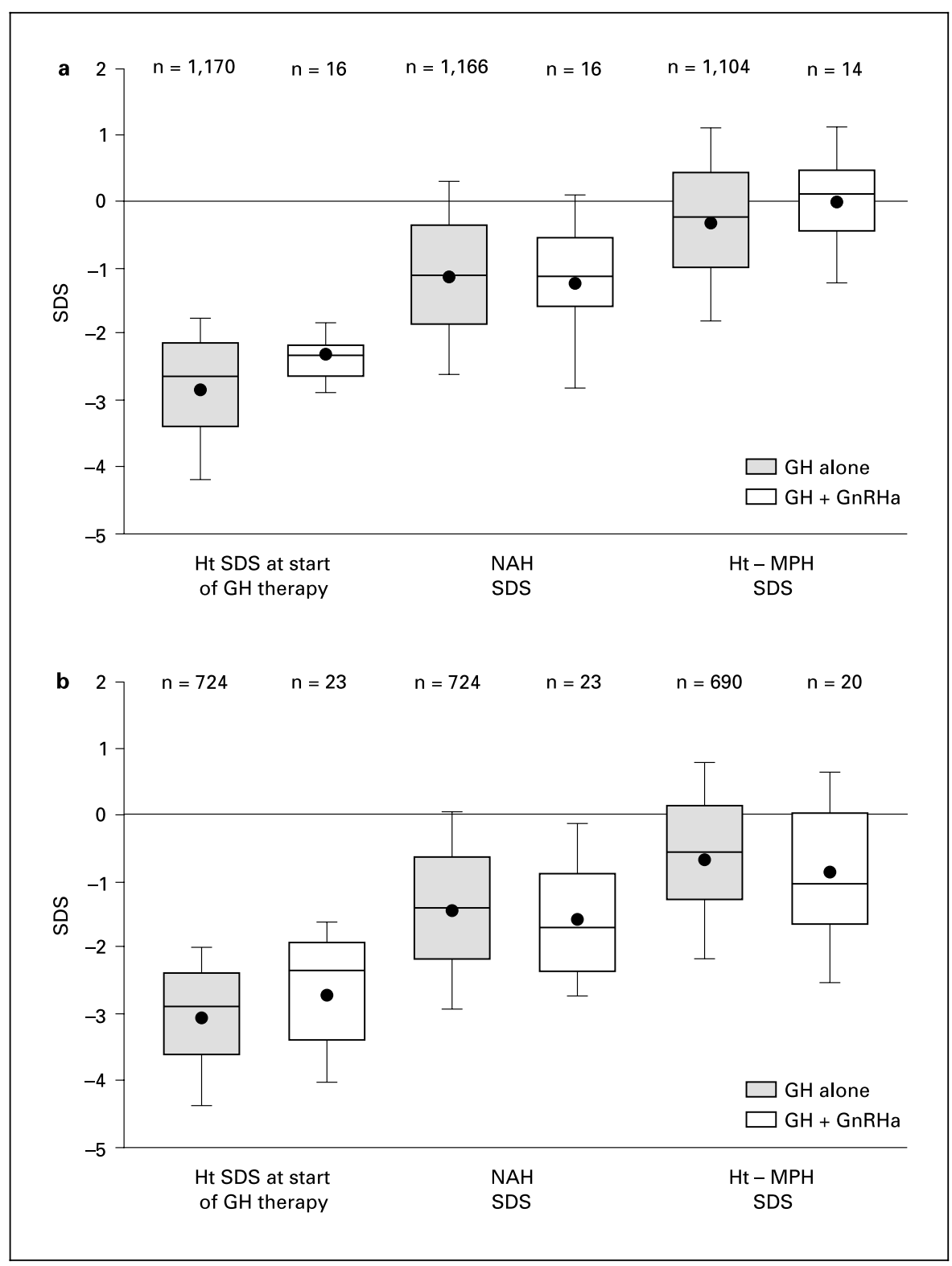

\begin{tabular}{|c|c|c|c|c|}
\hline & \multicolumn{2}{|l|}{ Boys } & \multicolumn{2}{|l|}{ Girls } \\
\hline & GH alone & $\mathrm{GH}+\mathrm{GnRHa}$ & GH alone & $\mathrm{GH}+\mathrm{GnRHa}$ \\
\hline Patients, $\mathrm{n}$ & 1,170 & 16 & 723 & 23 \\
\hline Age, years & 18.0 & 18.3 & 16.3 & 16.4 \\
\hline Bone age, years & 16.5 & 15.5 & 15.0 & 14.5 \\
\hline Ht SDS & -1.1 & -1.1 & -1.3 & -1.6 \\
\hline$\Delta \mathrm{Ht}$ SDS & +1.6 & +1.1 & +1.4 & +1.1 \\
\hline $\mathrm{Ht}-\mathrm{MPH}$ & -0.3 & -0.1 & -0.5 & -1.0 \\
\hline
\end{tabular}

All values, except for the number of patients, are expressed as medians. $\mathrm{Ht}=\mathrm{Height}$; $\mathrm{MPH}=$ mid-parental target height. 
Characteristics of the patient groups at NFH are shown in table 4. The bone ages in the $\mathrm{GH}+\mathrm{GnRHa}$ groups were lower than in the GH-treated groups, suggesting a potential for further growth. In male patients, the NFH closely approximated MPH in both groups, with the median differences being between -0.3 and -0.1 SDS (fig. 1a). In females, the NFH was not as close to MPH with a full 1.0 SDS difference $(\sim 6 \mathrm{~cm})$ in the $\mathrm{GH}+\mathrm{GnRHa}$ group (fig. 1b).

\section{Discussion}

Although the vast majority of experience with GnRHa in the treatment of children with gonadotropin-mediated sexual precocity has shown a slowing in the tempo of puberty, delay in skeletal maturation, and improvement in adult height over controls and pre-treatment predictions [31, 32], the addition of GnRHa to GH therapy regimens for patients with IGHD does not appear to have comparable value. Investigators conducting clinical studies of patients with GHD with delayed puberty or hypogonadotropic hypogonadism reported taller final heights $[13,17,18]$, suggesting that delaying pubertal progression in patients with IGHD may be a reasonable strategy. Such a treatment regimen in pubertal patients with GHD, however appealing it may seem, is not yet clearly documented to enhance final height $[22,24,25,27,28]$. Although two small, controlled trials did demonstrate substantial efficacy, similar findings were not reported in data from the NCGS database [30].

The data presented in this study of patients with IGHD treated with either GH alone or GH + GnRHa in the KIGS database largely support the earlier findings from the NCGS [30], demonstrating an equivocal efficacy for the addition of $\mathrm{GnRHa}$ to the $\mathrm{GH}$ treatment regimen. Although children treated with GH + GnRHa were older and had more advanced skeletal maturation at the start of the $\mathrm{GH}$ treatment than the GH-treated group, they were quite similar in height SDS and approximation to MPH at the onset of puberty (GH-alone group) and the start of GnRHa therapy (GH + GnRHa group). Growth during puberty in GH-treated boys was greater than in $\mathrm{GH}+$ GnRHa-treated boys, but the shorter MPH in the GH + GnRHa-treated boys allowed for a closer approximation to family height. In the girls, however, there were no benefits, and possibly even a deficit, from receiving $\mathrm{GH}$ alone.

Previous data in KIGS from patients with IGHD [16] have demonstrated the importance of height attained dur- ing the pre-pubertal period and the relatively small contribution of the height gained during puberty. These data strongly suggest that manipulation of growth treatments during puberty might be less successful than aggressive pre-pubertal management. Although recent data do not suggest that there is a long-term adverse effect on bone mineralization by halting pubertal maturation with GnRHa [33, 34], it has been of concern [35]. Furthermore, the delay of pubertal maturation in a child who is already of short stature may have a detrimental psychosocial impact. These concerns and the limited successes reported suggest that a cautious approach to the $\mathrm{GH}+$ GnRHa treatment regimen is merited.

In addition, in an effort to increase the final heights of patients with IGHD, the use of a high dose of GH during puberty has been studied, based on the rationale that the secretion of GH normally rises two- to fourfold during the pubertal growth spurt with dramatic concomitant increases in serum levels of insulin-like growth factor I (IGF-I). It is also known that the pubertal growth spurt normally accounts for approximately $17 \%$ and $12 \%$ of adult male and female height, respectively. In view of this, Mauras et al. [36] evaluated substantially increased doses of $\mathrm{GH}(0.1$ vs $0.043 \mathrm{mg} / \mathrm{kg} /$ day $)$ and found that the higher dose only resulted in a $4.6 \mathrm{~cm}$ increase in NFH. The mean height SDS achieved in the $0.043 \mathrm{mg} / \mathrm{kg} /$ day group (as in the earlier report [4]) was $-0.7 \pm 0.9$, but $0.0 \pm 1.2$ in the $0.1 \mathrm{mg} / \mathrm{kg} /$ day group. This outcome was certainly similar to the best data obtained with GnRHa, but concerns still remain regarding the high levels of IGF-I attained during such high $\mathrm{GH}$ dose regimens.

Collectively, these findings suggest that puberty is not the optimal period to attempt to enhance the final height outcome in patients with IGHD. Earlier diagnosis of GHD with concomitant initiation of GH treatment, progressive weight-related dose increments, strict attention to compliance with daily administration, and perhaps titration of doses of $\mathrm{GH}$ based on frequent measurements of IGF levels (or other GH-modulated peptides) may yield heights within the family target range.

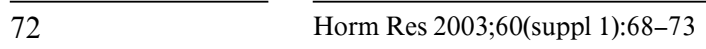

Reiter/Lindberg/Ranke/Price/ Albertsson-Wikland/Cowell/Bakker 


\section{References}

1 Bramswig JH, Schlosser H, Kiese K: Final height in children with growth hormone deficiency. Horm Res 1995;43:126-128.

2 Severi F: Final height in children with growth hormone deficiency. Horm Res 1995;43:138140 .

3 Birnbacher R, Riedl S, Frisch H: Long-term treatment in children with hypopituitarism: pubertal development and final height. Horm Res 1998;49:80-85.

4 Blethen SL, Baptista J, Kuntze J, Foley T, LaFranchi S, Johanson A: Adult height in growth hormone (GH)-deficient children treated with biosynthetic GH. The Genentech Growth Study Group. J Clin Endocrinol Metab 1997;82:418-420.

5 De Luca F, Maghnie M, Arrigo T, Lombardo F, Messina MF, Berasconi S: Final height outcome of growth hormone-deficient patients treated since less than five years of age. Acta Paediatr 1996;85:1167-1171.

6 MacGillivray MH, Blethen SL, Buchlis JG, Clopper RR, Sandberg DE, Conboy TA: Current dosing of growth hormone in children with growth hormone deficiency: how physiologic? Pediatrics 1998;102:527-530.

7 Grumbach MM, Bin-Abbas BS, Kaplan SL: The growth hormone cascade: progress and long-term results of growth hormone treatment in growth hormone deficiency. Horm Res 1998;49(suppl 2):41-57.

8 Bernasconi S, Arrigo T, Wasniewsk M, Ghizzoni L, Ruggeri C, Di Pasquale G, Vottero A, De Luca F: Long-term results with growth hormone therapy in idiopathic hypopituitarism. Horm Res 2000;53:55-59.

9 August GP, Julius JR, Blethen SL: Adult height in children with growth hormone deficiency who are treated with biosynthetic growth hormone: the National Cooperative Growth Study experience. Pediatrics 1998;102:512-516.

10 Cutfield WS, Lindberg A, Chatelain P, Price DA, Albertsson-Wikland K, Wilton P, Ranke MB: Final height following growth hormone treatment of idiopathic growth hormone deficiency in KIGS; in Ranke MB, Wilton P (eds): Growth Hormone Therapy in KIGS - 10 Years' Experience. Heidelberg-Leipzig, Johann Ambrosius Barth Verlag, 1999, pp 93-110.

11 Cutfield W, Lindberg A, Albertsson-Wikland K, Chatelain P, Ranke MB, Wilton P: Final height in idiopathic growth hormone deficiency: the KIGS experience. KIGS International Board. Acta Paediatr Suppl 1999;428:72-75.

12 Frisch H, Birnbacher R: Final height and pubertal development in children with growth hormone deficiency after long-term treatment. Horm Res 1995;43:132-134.

13 Price DA, Ranke MB: Final height following growth hormone treatment; in Ranke MB, Gunnarsson R (eds): Progress in Growth Hormone Therapy - 5 Years of KIGS. Mannheim, J\&J Verlag, 1994, pp 129-144.
14 Burns EC, Tanner JM, Preece MA, Cameron $\mathrm{N}$ : Final height and pubertal development in 55 children with idiopathic growth hormone deficiency, treated for between 2 and 15 years with human growth hormone. Eur J Pediatr 1981;137:155-164.

15 Bourguignon JP, Vandeweghe M, Vanderschuren-Lodeweyckx M, Malvaux P, Wolter R, DuCaju M, Ernould C: Pubertal growth and final height in hypopituitary boys: a minor role of bone age at onset of puberty. J Clin Endocrinol Metab 1986;63:376-382.

16 Ranke MB, Price DA, Albertsson-Wikland K, Maes M, Lindberg A: Factors determining pubertal growth and final height in growth hormone treatment of idiopathic growth hormone deficiency. Horm Res 1997;48:62-71.

17 Wit JM, Kamp G, Rikken B: Spontaneous growth and response to growth hormone treatment in children with growth hormone deficiency and idiopathic short stature. Pediatr Res 1996;39:295-302.

18 Hibi I, Tanaka T, Tanae A, Kagawa J, Hashimoto N, Yoshizawa A, Shizume K: The influence of gonadal function and the effect of gonadal suppression treatment on final height in growth hormone $(\mathrm{GH})$-treated $\mathrm{GH}$-deficient children. J Clin Endocrinol Metab 1989;69: 221-226.

19 Saggese G, Cesaretti G, Andreani G, Carlotti $\mathrm{C}$ : Combined treatment with growth hormone and gonadotropin-releasing hormone analogues in children with isolated growth hormone deficiency. Acta Endocrinol 1992;127: 307-312.

20 Toublanc JE, Couptrie C, Garnier P, Job JC: The effects of treatment combining an agonist of gonadotropin-releasing hormone with growth hormone in pubertal patients with isolated growth hormone deficiency. Acta Endocrinol 1989;120:795-799.

21 Adan L, Souberbielle JC, Zucker JM, PierreKahn A, Kalifa C, Brauner R: Adult height in 24 patients treated for growth hormone deficiency and early puberty. J Clin Endocrinol Metab 1997;82:229-233.

22 Balducci R, Toscano V, Mangiantini A, Municchi G, Vaccaro F, Picone S: Adult height in short normal adolescent girls treated with gonadotropin-releasing hormone analog and growth hormone. J Clin Endocrinol Metab 1995;80:3596-3600.

23 Saggese G, Pasquino AM, Bertelloni S, Baroncelli GI, Battinin R, Pucarelli I, Segni ME, Franchi G: Effect of combined treatment with gonadotropin releasing hormone analogue and growth hormone in patients with central precocious puberty who had subnormal growth velocity and impaired height prognosis. Acta Paediatr 1995;84:299-304.

24 Pasquino AM, Municchi G, Pucarelli I, Segni M, Mancini MA, Troiani S: Combined treatment with gonadotropin-releasing hormone analog and growth hormone in central precocious puberty. J Clin Endocrinol Metab 1996; 81:948-951.
25 Job JC, Toublanc JE, Landier F: Growth of short normal children in puberty treated for three years with growth hormone alone or in association with gonadotropin-releasing hormone agonist. Horm Res 1994;41:177-184.

26 Mericq MV, Eggers M, Avila A, Cutler GBJ, Cassorla F: Near final height in pubertal growth hormone (GH)-deficient patients treated with $\mathrm{GH}$ alone or in combination with luteinizing hormone-releasing hormone analog: results of a prospective, randomized trial. J Clin Endocrinol Metab 2000;85:569-573.

27 Walvoord EC, Pescovitz OH: Combined use of growth hormone and gonadotropin-releasing hormone analogues in precocious puberty: theoretic and practical considerations. Pediatrics 1999;104:1010-1014.

28 Codner E, Mericq V, Cassorla F: Optimizing growth hormone therapy during puberty. Horm Res 1997;48:16-20.

29 Mul D, Wit JM, Oostdijk W, Van den Broeck J: The effect of pubertal delay by GnRH agonist in GH-deficient children on final height. J Clin Endocrinol Metab 2001;86:4655-4656.

30 Kohn B, Julius JR, Blethen SL: Combined use of growth hormone and gonadotropin-releasing hormone analogues: the National Cooperative Growth Study Experience. Pediatrics 1999; 104:1014-1017.

31 Conn PM, Crowley WF Jr: Gonadotropinreleasing hormone and its analogs. Annu Rev Med 1994;45:391-405.

32 Partsch CJ, Heger S, Sippell WG: Management and outcome of central precocious puberty. Clin Endocrinol (Oxf) 2002;56:129-148.

33 Van der Sluis IM, Boot AM, Krenning EP, Drop SL, De Muinck Keizer-Schrama SM: Longitudinal follow-up of bone density and body composition in children with precocious or early puberty before, during, and after cessation of GnRH agonist therapy. J Clin Endocrinol Metab 2002;87:506-512.

34 Heger S, Partsch CJ, Sippell WG: Long-term outcome after depot gonadotropin-releasing hormone agonist treatment of central precocious puberty: final height, body proportions, body composition, bone mineral density, and reproductive function. J Clin Endocrinol Metab 1999;84:4583-4590.

35 Antoniazzi F, Bertoldo F, Zamboni G, Valentini R, Sirpresi S, Cavallo L, Adami S, Tato L: Bone mineral metabolism in girls with precocious puberty during gonadotrophin-releasing hormone agonist treatment. Eur J Endocrinol 1995;133:412-417.

36 Mauras N, Attie KM, Reiter EO, Saenger P, Baptista J: High dose recombinant human growth hormone $(\mathrm{GH})$ treatment of $\mathrm{GH}$-deficient patients in puberty increases near-final height: A randomized, multicenter trial. Genentech, Inc., Cooperative Study Group. J Clin Endocrinol Metab 2000;85:3653-3660. 